\title{
La Teoría General y los Conflictos Territoriales de Aplicación de la Legislación Cooperativa del Sistema Autonómico
}

\author{
Jaime Lluis y Navas \\ Dr. en Derecho y en F. y Letras \\ Académico correspondiente de la \\ Academia Nacional Argentina de Derecho y C. Sociales
}

\section{Indicaciones previas}

Nos proponemos comparar en este trabajo las Reglas Generales de las leyes cooperativas españolas del último cuarto del siglo $\mathrm{xx}$, es decir, las promulgadas bajo el sistema político que ha sucedido al franquismo. Pero el estudio comparativo de las variantes de las legislaciones que nos van a ocupar requiere un recordatorio de las condiciones generales en que aparece esa normativa. $Y$ aún conocidas, creemos necesario destacar ciertos hechos que alcanzan a las soluciones jurídicas.

\section{Condicionamiento del cooperativismo}

A) Condicionamiento ideológico. El cooperativismo inicial forma parte de la corriente obrerista que reacciona frente a las tristes consecuencias del liberalismo del siglo XIX. Tan es así que sus promotores lo son a la vez del socialismo, del comunismo y del anarquismo. Posteriormente estas corrientes sufren un proceso de diferenciación. El cooperativismo pasa a caracterizarse por cuanto propugna la socialización mediante micro-entidades, frente al socialismo decimonónico y al comunismo que propugnan las macro-sociedades. Es decir, mientras estos últimos son partidarios de la propiedad estatal de los medios de producción (su asignación a la macro-sociedad estatal), el cooperativismo propugna asignar las entidades económicas a los trabajadores, suprimiendo por esta vía los patronos capitalistas (es decir, propugnan la solución del problema obrero mediante la creación de las micro-sociedades empresariales). 
Por otra parte el cooperativismo inicial sufrió muchos fracasos hasta que el éxito de la Cooperativa de Consumo de Rochdale acreditó que las cooperativas eran entidades susceptibles de ser viables. Pero ello tuvo otra consecuencia. La cooperativa de Rochdale lo era de consumo, lo que dio lugar a que los principios en que trató de justificarse el movimiento cooperativo se formulasen de modo directamente vinculado a la cooperación de consumo ${ }^{1}$.

B) Evolución histórica. Una vez consolidada la existencia de cooperativas, otros sectores del mundo económico desvinculados ideológicamente del cooperativismo inicial advierten que pueden servirse del sistema de sociedades cooperativas. Así aparecen cooperativas de grupos sociales desvinculados de los que originaron las primeras cooperativas: cooperativas de consumo de funcionarios, cooperativas de elaboración colectiva y comercialización de productos agrícolas, cooperativas de crédito impulsadas por diversos Colegios profesionales, etc.

Estas nuevas cooperativas dan lugar a una diversificación en las posturas doctrinales frente al fenómeno cooperativo: $1 .^{\circ}$ un sector doctrinal sigue militando en un ideal que propugna el sistema de empresas cooperativas como sistema general de la vida económica, podríamos calificar a esta corriente de cooperativismo radical. 2. ${ }^{\circ}$ Otra corriente, frecuente entre los juristas especialistas en derecho mercantil, ve en las cooperativas una forma más de sociedades de fines económicos, caracterizada por la variabilidad de capitales; es la postura de Vicente y Gella ${ }^{2}$ y podríamos considerarla plenamente mercantilista. 3. ${ }^{\circ}$ Otro sector doctrinal que podemos calificar de intermedio, formula la teoría de los tres sectores: público, privado y cooperativo. Personalmente entendemos que las entidades cooperativas han contribuido a una mayor ductilidad y mejor funcionamiento de los sistemas económicos tanto de tipo capitalista como comunista ${ }^{3}$. Pero que

1 En los albores del siglo xx, en España la cooperación de consumo seguía siendo preponderante dentro del conjunto cooperativo. Según el Instituto de Reformas Sociales, en 1904, de las 274 cooperativas existentes en España, 182 eran exclusivamente de consumo, 27 eran mixtas (combinaban el consumo con otra finalidad) y sólo 65 obedecían a finalidades de otra índole. Datos recogidos en la Enciclopedia Jurídica Seix, T. ${ }^{\circ}$ IX (Barcelona, S.A., hacia 1912), voz «cooperativa», pág. 481.

2 Véase A. VICENTE y GelLA, Introducción al Derecho mercantil comparado, Barcelona, 1941, pág. 153.

3 Véase G. AKSENIENOK, «Le Droit kolkhozien», en la ob. col. dirigida por P. RoMACHKIN, Principes du Droit sovietique, Moscú, S.A. (hacia 1966), págs. 328 y sig. 
su función es complementaria de los respectivos sistemas y que sería exagerado atribuirle la condición de tercer factor de trascendencia equiparable a la de los sectores público y privado clásicos.

C) Condicionamiento técnico. Por su misma razón de ser las cooperativas constituyen sociedades dirigidas a constituir empresas ${ }^{4}$. De ahí que para prosperar hayan de satisfacer los requisitos de toda sociedad (disponer de directivos y estatutos, etc.) y de toda empresa (organización y racionalización científica del trabajo, contabilidad, etc.). Pero han de disponer de estos elementos, como es lógico, adaptados a las características de las cooperativas. En todo caso ello implica un condicionamiento técnico.

\section{Triple fuente de regulación}

A) La Alianza Cooperativa Internacional. Al igual que otros movimientos fruto de la reacción obrerista del siglo XIX, el cooperativismo ha constituido una confederación internacional, la Alianza Cooperativa Internacional $(\mathrm{ACl})$. Este organismo no tiene autoridad directa sobre los Estados; pero los movimientos vinculados a los ideales originarios del cooperativismo tratan de lograr la efectividad de las soluciones propugnadas por la $\mathrm{ACl}$. De ahí la fuerza política indirecta de dicha organización internacional. Como tendremos ocasión de ver, las orientaciones de la $\mathrm{ACl}$ las recogen nuestros legisladores, en ocasiones, en los preámbulos de las leyes de cooperativas, y en otras en el propio articulado de las mismas.

B) La Unión Europea. Hasta el presente la Unión Europea ha fracasado como confederación política, pero ha tenido éxito como Mercado Común ${ }^{5}$. Al tener éxito como unión económica ha sentido la necesidad de regular con más o menos detalle las diversas formas de sociedades mercantiles. De ahí que igual que haya fijado la normativa básica de las Anónimas y Limitadas lo haya hecho con las cooperati-

4 Véase Waldemar Arecha, La empresa comercial, Buenos Aires, 1948, pág. 247, R. NuÑEZ LAGOS, "La empresa como objeto de negocios jurídicos», Revista General de Legislación y Jurisprudencia, núm. 175 (1944), pág. 180 y J. LLUIS y NAVAS, Empresa y propiedad. Su conceptuación jurídica, Barcelona, 1976, pág. 31.

5 Véase Fernando Díez Moreno, Manual de Derecho de la Unión Europea, Madrid, 1996, pág. 24 y sig. y J. LLUIS y NAVAS, «El sistema jurídico de la Unión Europea», Anales de la Academia Nacional de Derecho y Ciencias Sociales (Córdoba de Argentina), 2002, págs. 99 y sig. 
vas. Si la primera fuente de regulación tiene una raíz esencialmente ideológica, la segunda la tiene técnica. Ambas por tanto reflejan los condicionantes que hemos visto más arriba.

C) La ordenación pública. El desarrollo de cooperativas ha pedido su regulación, lo que a su vez se ha visto afectado por los sistemas políticos vigentes. Ello se ha reflejado en las siguientes fases; todas matizadas por el sistema político imperante:

a) Bajo la Monarquía canovista se abre a una modesta regulación de las cooperativas, por dos vías: un artículo del Código de Comercio y la Ley de Asociaciones de Sagasti que por su elasticidad se abría a toda suerte de entidades, desde un Asociación musical a un Club de futbol o una cooperativa ${ }^{6}$. Esta doble raíz legislativa refleja los cambios y dualidad de posturas frente a las cooperativas: su consideración como empresas mercantiles por una parte y por otra su consideración como asociaciones dirigidas a satisfacer un ideal ${ }^{7}$.

b) En los albores del siglo xx se promulgan diversas normas puntuales, sea sobre cooperativas determinadas (Ley de los llamados Sindicatos Agrícolas, Ley de Colonización Interior de 1907, Ley de Casas Baratas de 1911, etc.), sea sobre su tratamiento tributario (R.D. de 1892 sobre la Contribución Industrial, Ley de 1900 sobre la de Utilidades, Reglamento de la Contribución Industrial de 1911, etc.). Es decir se promulga una legislación modesta propia de la política social y económica de la época ${ }^{8}$.

c) La II República promulgó la primera ley completa de cooperativas española. La legislación republicana tiene entre otras las siguientes notas: 1. ${ }^{\circ}$ El fondo de la ley responde a la ideología imperante en aquel período; combinación de las posturas de los socialistas y de lo que pudiéramos llamar izquierda pequeño-burguesa. 2. ${ }^{\circ}$ Establece el principio de que la legislación

6 F. López-Nieto y Mallo, Manual de Asociaciones, Madrid, 1988, págs. 30-55 y J. Lluis y NAVAS, Derecho de asociaciones, Barcelona, 1967, págs. 10 y sig.

7 Julio Rodríguez Frutos, "Asociación y cooperativismo en Béjar», Estudios cooperativos núm. 48 (1978), págs. 59 y sig.

8 Véase Francisco SAlINAS RAmOS, El primer marco jurídico del cooperativismo agrario, Estudios cooperativos, núm. 39 (1976), págs. 41 y sig. Véase también Miguel A. CiUro CALDANI, «Aportes para la comprensión jusfilosófica del Código Civil. Bases para su análisis cultural», en Homenaje a Dalmacio Vélez Sarsfield, T V, Córdoba de Argentina, 2000, págs. 327 y sig. José M. Montolıo, «Las Cooperativas en España. Evolución y perspectivas», Anuario de Estudios cooperativos (1992), págs. 31 y sig. 
cooperativa es transmisible mediante Estatuto de Autonomía, puesto que la única región que recibió un Estatuto (Cataluña) entre las competencias transferidas vio incluida la legislación sobre cooperativas.

d) Bajo el franquismo se conserva el sistema de ley específica de cooperativas, pero se adopta el de legislación única suprimiéndose por tanto la especial catalana. La nueva ley se adaptó al sistema político franquista: encuadramiento de las cooperativas en la Obra Sindical de Cooperación a su vez dependiente de la Organización Sindical pública de la época, etc.

e) La segunda restauración borbónica, en lo que al cooperativismo se refiere, ha optado por una nueva ley general basada en principios más cercanos a los de la época republicana, lo que ha supuesto la desaparición de la Obra Sindical de Cooperación y del encuadramiento público de las cooperativas. Por otra parte ha generalizado la atribución a las autoridades regionales de la potestad legislativa en esta materia. Con todo hemos de hacer una importante distinción: $1 .{ }^{\circ}$ Ciertos estatutos de autonomía trasfieren la materia cooperativa desde su inicio (Estatutos de Andalucía, Cataluña, Galicia, Navarra, Valencia y Vascongadas). 2. ${ }^{\circ}$ Los restantes territorios reciben esta potestad por vía de modificación de sus estatutos (Leyes Orgánicas 1/94 a 11/94, dictadas respectivamente para Asturias, Aragón, Baleares, Canarias, Cantabria, ambas Castillas, Extremadura, Madrid, Murcia y Rioja). 3. ${ }^{\circ}$ Ceuta y Melilla carecen de atribuciones legislativas en materia de cooperativas.

Los cambios legislativos, tanto de la II República como del franquismo y los de la Monarquía restaurada son lógica consecuencia de los ideales políticos a que obedecían estos regímenes, lo que confirma la politización de la legislación sobre cooperativas, politización herencia del origen histórico de estas entidades 9 .

9 Véase Pablo BuItrón AndRADE, «Evolución del Consejo Superior de Cooperativas», Anuario de Estudios Cooperativos (1999), págs.191 y sig. y J. LLUIS y NAVAS, «La evolución de las directrices fundamentales de la legislación cooperativa española», Estudios cooperativos núm. 39 (1976), págs. 3 y sig. 


\section{Consecuencias}

Lo acabado de señalar ha tenido las siguientes consecuencias:

A) Pluralidad normativa. Como resultado de cómo se han aplicado los criterios cooperativistas en materia legislativa hemos llegado a generalizar el sistema de leyes regionales en esta materia.

El autor de estas líneas ha sido y se ha proclamado foralista y regionalista desde hace más de medio siglo y bajo sistemas poco propicios al mismo ${ }^{10}$. No obstante ha de recordar que, en un sistema de Estado común con autonomías, las facultades atribuidas a los gobiernos autonómicos han de obedecer lógicamente a alguna de estas razones: 1. Por exigirlo las características geográficas de algunos territorios (caso de los cabildos canarios y de los consejos insulares de las Baleares, y también de la especial situación de Ceuta y Melilla). 2. Por pedirlo la tradición y los precedentes históricos de determinados territorios (caso de los Mozos de Escuadra en Cataluña, de los Forales y Miqueletes en los territorios vasco-navarros, etc.). 3. ${ }^{\circ}$ Por pedirlo las características propias de determinados territorios (caso de las lenguas regionales en las regiones españolas que no son exclusivamente castellanoparlantes; caso también del derecho foral civil, en la medida en que conviene conservarlo, etc.). 4. ${ }^{\circ}$ Por un criterio de mayor eficacia (por ejemplo la conservación de monumentos en que el poder central está demasiado lejos para valorar las cosas debidamente, caso de las denominaciones de origen, etc.). 5. ${ }^{\circ}$ Por cuanto se consigue una mayor baratura con igual eficacia (es posible que existan supuestos en que ello sucede). $6{ }^{\circ}$ Por tratarse de materias en que es conveniente la superposición de instituciones de la autoridad central y de la territorial (por ejemplo, tratándose de Museos y Bibliotecas).

Desgraciadamente hemos pasado de un sistema franquista que practicaba el «art pour l'art» de la uniformidad jurídica a otro que distribuye las competencias en función de un tira y afloja político en que con demasiada frecuencia las ambiciones pesan mas que criterios de buen gobierno. Centrándonos en las cooperativas, la proliferación de trasferencias y de promulgaciones legislativas dudamos haya obedecido a criterios racionales. Es más, el que unas regiones hayan recibido esas atribuciones en sus estatutos originarios y otro grupo en un bloque de normas dictadas en 1994 (casi veinte años después del falle-

10 J. LLUIS Y NAVAS, «El Derecho y la política», Humanidades (1951), págs. 68 y sig. 
cimiento del anterior Jefe del Estado) hace muy dudosos los fundamentos de una política de esa índole. Hemos de señalar por consiguiente: $1 .^{\circ}$ La transmisión a las autoridades regionales de la administración cooperativa (registros, tramitación de los expedientes de constitución) está dentro de la lógica de un sistema autonómico. 2. ${ }^{\circ}$ En principio no lo está la proliferación de normas legales (más en momentos en que la incorporación a la Unión Europea pide armonización de normas) pues la variedad en este caso encierra, entre otros, el peligro de dificultar las actuaciones «mercantiles» de las cooperativas y consiguientemente de su desarrollo. 3. ${ }^{\circ}$ Sí estaría en cambio justificada una normativa foral centrada en las necesidades que resultan de ciertas particularidades territoriales, por ejemplo el régimen fiscal de los territorios vasco-navarros pide una norma especial en materia de tributación de las cooperativas de esos territorios ${ }^{11}$.

B) Condicionamiento externo. Las razones expuestas dan lugar a un condicionamiento externo de la ordenación cooperativa que se plasma del modo que seguidamente señalamos:

a) Todas las normas se ven afectadas por la legislación de la Unión Europea; si bien no lo recogen en su articulado, aún cuando algunas lo hagan en la Exposición de Motivos. Están en este caso la Ley General de 1999, la de Aragón, la catalana del 2002, la de Castilla La Mancha del mismo año, la navarra de 1996, así como las vascongadas de 1982 y 1993. La de Madrid lo hace indirectamente por la vía de referirse a los Tratados suscritos por España12.

b) La mayoría de nuestras leyes de cooperativas optan por referirse en sus preámbulos a la $\mathrm{ACl}$, particularmente especificando que están a sus criterios, sea para fijar el concepto de cooperativa, sea para aplicar los Principios de la Alianza. Es el caso de la Ley General de 1987 y las de Andalucía de 1985, Cataluña de 1982, Extremadura, Galicia, Madrid, navarras de 1989 y 1996, Rioja, vascongadas de 1982 y 1993, y valenciana del 2003. Las que incluyen la referencia a la $\mathrm{ACl}$ en la definición de sociedad cooperativa las señalamos más adelante.

11 Por supuesto, desde el momento en que las autoridades autónomas ejercen una función en materia cooperativa, ello pide que dispongan de las instituciones adecuadas, incluso si sus facultades fueran limitadas. Véase Buitrón, Ob. Cit., pág. 192.

12 Véase Moreno, Ob. Cit., págs. 66 y sig. y Christian PhiliP, Droit Social européen, París, 1985, págs. 180 y sig. 
c) La ACl en su Congreso de Manchester formuló una definición de las sociedades cooperativas que recogen las leyes de Baleares, Extremadura, Madrid y Rioja.

\section{Normativa general}

\section{Concepto}

A) Indicación previa. El conjunto de leyes españolas ofrece definiciones muy variadas de las sociedades cooperativas. Estas definiciones, con frecuencia, en lugar de recoger los elementos que configuran las cooperativas (función propia de las definiciones, a fin de fijar la esencia de la idea o concepto con que operamos), se extienden sobre elementos impropios de las definiciones, pues consisten en enumeraciones más o menos acertadas según los casos sobre otros aspectos de la legislación cooperativa: fundamento de la misma, requisitos que ha de satisfacer, etc. Pero introducir estos asertos en la fijación del concepto (en lugar de tratar de ellos en el lugar que les corresponde) es un factor de confusión que en nada favorece la recta aplicación del Derecho.

Como hemos apuntado en otras ocasiones ${ }^{13}$ consideramos que técnicamente las cooperativas son sociedades de capital y miembros variables, que tienen por finalidad realizar con sus propios socios las operaciones económicas que constituyen la finalidad de las mismas. Su carácter societario en el sentido de constituir entidades integradas por varias personas es tan evidente que no pide aclaraciones adicionales. Los otros elementos de su conceptuación también los creemos evidentes por las siguientes razones:

a) La doble variabilidad de capitales y miembros, lo es de dos elementos íntimamente interconectados entre sí. Ha sido reconocida siempre como dato diferencial de otras sociedades de fines económicos ${ }^{14}$. Más en concreto, constituye la susceptibili-

13 J. LluIS Y NAVAS, Derecho de cooperativas, T. ${ }^{\circ}$, Barcelona, 1972, pág. 27 y sig.

14 Vicente y Gella, Ob. Cit., pág. 155 y Narciso Paz Canalejo, El nuevo derecho cooperativo español, Madrid, 1979, págs. 27 y 205. Con todo también en los sistemas comunistas clásicos y autogestionados, las cooperativas se diferencian de otro tipo de empresas. Véase Romachkin Aksenienok, Ob. Cit., pág. 330 y J. Lluis y NAVAS, «La cooperación clásica y el socialismo autogestionario yugoslavo», Estudios cooperativos, núm. 41 (1977), págs. 9 y sig. 
dad de variar el número de miembros y de aportaciones de capital sin precisar reformar los estatutos. Es una característica directamente relacionada con las motivaciones iniciales del movimiento cooperativo y hoy generalmente admitida, lo que supone que ha sido aceptada incluso por las corrientes que, desvinculadas de los ideales sociales de los primeros cooperativistas, ven en estas entidades una forma complementaria de desarrollar actividades económicas.

b) La realización de operaciones con los propios socios no está técnicamente vinculada a la variabilidad (en principio cabrían sociedades de elementos variables dirigidas a operar con terceros). En cambio está vinculada ideológicamente pues en los orígenes de la cooperación ambas características de estas entidades obedecían a la misma finalidad: eliminar el intermediario capitalista cuya función asumía la cooperativa y hacerlo por una razón de política social ${ }^{15}$.

c) Destacamos que las operaciones que la cooperativa desarrolla con los socios son las que constituyen la finalidad de la entidad por cuanto a título instrumental precisa efectuar operaciones con terceros. Así las cooperativas de consumo venden a los socios, pero compran a terceros. Las de producción emplean a sus socios pero venden al público, etc.

Las variaciones que ofrecen las definiciones de conjunto legislativo español son muy grandes, por lo que procederemos a analizar los elementos que contienen.

B) Calificación como entidad societaria. Esta nota es tan evidente que la recogen todas las leyes que nos ocupan, utilizando en general el término sociedad. Con todo cabe señalar las siguientes variantes:

a) Utilizan la calificación como asociaciones prescindiendo del término sociedad (sin perjuicio de que este término aparezca en el articulado) las leyes de Madrid y de La Rioja.

b) Utilizan en la definición exclusivamente la expresión "sociedad» las leyes andaluza de 1985, de Castilla-La Mancha de 2002, gallega de 1998, navarras de 1989 y 1996 y vascas de 1982 y 1993.

15 Véase Ignacio Arroyo Martínez, Legislación sobre cooperativas, Madrid, 1995, pág. 13, Montolio, Ob. Cit., pág. 31, N. PAZ, Ob. Cit., pág. 157 y Lluis, Derecho..., T. I, págs. 28 y sig. 
c) Combinan en la definición ambos términos las leyes generales de 1987 y 1996 y las de Aragón, Baleares, Castilla y León, catalanas de 1983, 1992 y 2002 y de Extremadura ${ }^{16}$.

d) Las leyes valencianas de 1985 y 2003 emplean la expresión «agrupación».

C) Variabilidad del capital. Todas las leyes admiten la variabilidad de capital en su articulado. Pero siguen criterios distintos cuando se trata de recoger este elemento en las respectivas definiciones de las cooperativas:

a) Incluyen la referencia directa a la variabilidad del capital la Ley General de 1987 y las territoriales catalanas de 1992 y 2002 así como las de Galicia, Castilla-La Mancha y la vascongada de 1982.

b) Las restantes carecen de una referencia directa a la variabilidad de capital. Pero la tienen implícita por tres vías: $1 .{ }^{\circ}$ Por cuanto su articulado sanciona la variabilidad del capital (regla general). 2. ${ }^{\circ}$ Por remitirse a los Principios de la $\mathrm{ACl}$ (más adelante señalamos las normas que adoptan esta técnica). 3. ${ }^{\circ}$ Otro grupo de normas define las cooperativas por remisión al conjunto del articulado de la ley que las regula (solución de la leyes de Aragón, andaluza de 1985 y Navarra de 1989).

Advertirá el lector que en los supuestos en que se ha dictado más de una ley de cooperativas, se ha cambiado frecuentemente de criterio en la referencia expresa a la variabilidad del capital. Curiosamente la Ley General y la Catalana han seguido evoluciones distintas pues mientras en la catalana originariamente no se incluía la referencia directa a los criterios de la $\mathrm{ACl}$, sí se incluye en las leyes de 1992 y 2002 y lo contrario resulta comparando las Leyes Generales de 1987 y 1999. Evolución en dirección contraria a la catalana resulta de comparar la Ley Vascongada de 1982 con las de 1985 y 2002. En cambio las leyes valencianas han seguido un criterio constante en este extremo.

D) Variabilidad de personas. Propiamente la variabilidad de miembros no es nota exclusiva de las cooperativas. Es más, constituye la

16 La ley catalana de 1992 es propiamente un Decreto Legislativo que refunde las modificaciones de la Ley de 1983, introducidas mediante otra de 1991. La Ley Valenciana de 1982 fue modificada mediante otra Ley de 1995. Por lo tanto todas las referencias que en este trabajo hacemos a la legislación de ambos territorios hay que entenderlas con esta precisión que formulamos una sola vez con el propósito de evitar repeticiones. 
nota ordinaria de todas las sociedades. Sólo están exceptuadas las constituidas en consideración a características personales propias de los asociados. Lo realmente característico de las cooperativas es la vinculación entre la variación de los socios y la variación del capital. En todo caso entre las leyes de cooperativas que nos ocupan advertimos las siguientes variantes:

a) Omiten en la definición la referencia a la variabilidad de socios las leyes de cooperativas de Aragón, andaluza de 1985, Baleares, Castilla-La Mancha, catalana de 1983, Extremadura, Madrid, Rioja, valencianas de 1985 y 2003 y vascongada de 1983. No obstante, la variabilidad resulta de su articulado cuando no de los principios que recogen.

b) Incluyen en su definición la regla de libertad de pertenencia (libre adhesión y baja) que implica la variabilidad de los integrantes de la respectiva cooperativa las Leyes Generales de 1987 y 1999, así como las de Castilla y León, catalanas de 1992 y 2002 y de Galicia.

c) La Ley Vasca de 1982 hacía referencia directa a la variabilidad de socios.

d) La Ley Navarra de 1996 también contiene una referencia a la variabilidad de los socios pero por la vía indirecta de incluir como apéndice a la definición la enumeración de principios, entre ellos los de variabilidad y de libre adhesión de los miembros de las cooperativas.

E) Voluntariedad de pertenencia. La voluntariedad, tanto en la constitución de las sociedades, como en la incorporación a las mismas y en la continuidad de pertenencia, dista mucho de ser elemento definitorio ni de las cooperativas ni de otras formas asociativas privadas. Pues como regla general lo exigen la regla de autonomía de la voluntad y además la carencia de voluntad constituiría un vicio del consentimiento (art. 1261 del Código Civil). No obstante, por razones doctrinales, la mayoría de nuestras leyes tienden a incluir la voluntariedad como rasgo definitorio de las cooperativas. No obstante, entre ellas hemos de formular ciertas distinciones más formales que sustantivas:

a) Especifican que la pertenencia a la cooperativa es voluntaria las leyes de Baleares, Extremadura, Madrid, Rioja y todas las valencianas.

b) Indican que la pertenencia a las cooperativas está sometida a la regla de libre adhesión las Leyes Generales de 1987 y 1999, las catalanas de 1992 y 2003 y la de Galicia. 
c) Utiliza la doble expresión (voluntariedad y libre adhesión) la ley de Castilla y León.

d) Carecen de una referencia directa (si bien figura implícita por remisión sea a los principios, sea al contenido de la ley) las de Aragón, andaluza de 1985, Castilla-La Mancha, la catalana de 1983 (a diferencia de las de 1992 y 2002, las navarras de 1989 y 1996 y las vascas de 1982 y 1993.

F) Generación de una empresa. Toda sociedad de fines económicos genera una empresa puesto que la empresa es por definición una organización de elementos de diversa naturaleza coordinados en función de una finalidad económica ${ }^{17}$. Las cooperativas no son excepción de esta regla. Con todo, las leyes que estamos estudiando varían al recoger esta característica en las definiciones:

a) Un considerable grupo de disposiciones señala que la sociedad cooperativa constituye una empresa y especifica que se trata de una empresa colectiva, variando ligeramente los términos con que se formula esta indicación: 1. ${ }^{\circ}$ Las leyes de Baleares, Extremadura, Galicia, Madrid y Rioja se refieren a una empresa de propiedad conjunta. $2 .^{\circ}$ Mas escuetamente la de Castilla-La Mancha hace referencia a la empresa conjunta. 3. ${ }^{\circ}$ Las leyes navarras de 1989 y 1996 utilizan la expresión empresa en común. $4 .^{\circ}$ Término similar es el de las disposiciones valencianas de 1995 y 2003: empresa colectiva.

b) Otro grupo de disposiciones gira en torno a la idea de actividad coincidiendo en que esta actividad es económica o económicasocial, pero variando el grado en que se califica de actividad empresarial: $1 .^{\circ}$ La ley aragonesa y la de Castilla y León, así como las Leyes Generales de 1987 y 1994 sustentan que estamos ante una actividad de naturaleza empresarial. 2. ${ }^{\circ}$ Las leyes catalanas de 1983, 1992 y 2002 entienden que estamos ante una actividad empresarial de base colectiva. Por su parte la ley andaluza de 1985 afirman que estamos ante una actividad socioeconómica.

c) La legislación del País Vasco ha registrado un cambio pues la ley de 1982 hacía referencia al desarrollo de una actividad económica y/o social mientras la de 1993 dice que la cooperativa desarrolla una empresa con un objetivo económico y social.

17 Véase la nota 4 y José FAnelu, Introduzione alla teoria giuridica dell'impresa, Milán, 1950, pág. 12 y N. Paz, Ob. Cit., pág. 205. 
Precisando el alcance de las diferencias acabadas de apuntar hemos de señalar: 1. ${ }^{\circ}$ Formalmente la diferencia de concepción es importante pues la empresa es una organización, mientras la actividad encierra un comportamiento; realmente la diferencia es nimia pues la empresa es una organización dirigida a desarrollar una actividad económica y la actividad contemplada en las definiciones acabadas de considerar es precisamente la actividad empresarial, se reconozca expresamente como hemos visto se hace en un grupo de definiciones, o sea de modo implícito como hacen las restantes centradas en la idea de actividad. 2. ${ }^{\circ}$ Las referencias al carácter colectivo sea de las empresas o sea de su actividad, más que un imperativo técnico de las definiciones reflejan la influencia de las corrientes doctrinales auspiciadas por la $\mathrm{ACl}$.

G) Finalidad. Como recordaría Pero Grullo, la finalidad de todas las entidades de naturaleza económica consiste precisamente en desarrollar actividades económicas. No obstante, tratándose de cooperativas, y por las razones histórico doctrinales señaladas al iniciar este trabajo, la fijación del objetivo tiene algunas importantes matizaciones: $1{ }^{\circ}$ Todas la leyes sobre esta materia evitan referencias a la actividad mercantil. 2. ${ }^{\circ}$ Al fijar el objeto de las sociedades cooperativas, nuestros legisladores no se limitan a señalar la finalidad económica, pero lo hacen con fórmulas que implican ciertas variantes, como veremos a continuación.

a) Respecto de la dimensión económico social hemos de señalar: 1. Las leyes valencianas de 1985 y 2003 son las únicas que no la recogen explícitamente, aún cuando la sancionan de modo implícito, al referirse a la actividad empresarial (que implica una actividad económica) y al servicio de los socios (que constituye una finalidad social). 2. ${ }^{\circ}$ Las restantes leyes se refieren de modo expreso a la dimensión económico social; es decir, a la dimensión económica propia de toda empresa, y añaden la finalidad social. 3. ${ }^{\circ}$ Las leyes de Baleares y Extremadura van más lejos pues adicionan una tercera finalidad: la cultural.

b) Sobre el modo como recogen la referencia a la dimensión económico social (y en su caso a la cultural), se advierten diferencias, mas doctrinales que de trascendencia práctica: $1 .{ }^{\circ}$ Se refieren propiamente a la actividad económico-social las leyes de Aragón, andaluza de 1985, navarras de 1989 y 1996 y la del País Vaso de 1987. 2. ${ }^{\circ}$ Añade la idea de actividad para satisfa- 
cer necesidades la Ley Vasca de 1993. 3. ${ }^{\circ}$ Hace referencia a las necesidades e intereses (económico-sociales) la Ley General de 1987. 4. Incluyen la idea de actividad para satisfacer aspiraciones y necesidades la Ley General de 1999 así como las de Baleares, ambas Castillas, Extremadura, Galicia, Madrid y Rioja. 5. ${ }^{\circ}$ La Ley Catalana de 1982 contemplaba la mejora de la condición de los socios y las de 1992 y 2002 han conjugado las ideas de necesidad, interés y mejora.

H) Sujetos beneficiarios. Toda sociedad se constituye con el propósito de beneficiar a personas determinadas, sea directa o indirectamente. Así lo pide un evidente imperativo axiológico dirigido a alcanzar el bien y dirigido precisamente a hacerlo colectivamente para superar las limitaciones humanas ${ }^{18}$. En la mayoría de los casos los pretendidos beneficiarios son los propios miembros de la entidad, si bien la regla no es general (caso de las organizaciones de fines benéficos, por ejemplo). Respecto de las cooperativas, las definiciones de nuestros sistemas legales arrojan las siguientes diferencias en sus definiciones:

a) Se centran en las ventajas que han de proporcionar a los socios la Ley General de 1999 y las de Aragón, Baleares, Castilla y León, Extremadura, Madrid, Rioja y las de la Ciudad y Reino de Valencia de 1985 (tras la reforma de 1995) y del 2003 y del País Vasco de 1993. Adviértase que, en los casos de territorios que han promulgado más de una ley, adoptan esta solución las más modernas.

b) Sustentan que han de beneficiar conjuntamente a los socios y «la Comunidad» la Ley General de 1987, y las de Andalucía de 1985, Castilla-La Mancha, Galicia, navarras de 1986 y 1996 así como la valenciana de 1985 (en su redacción originaria) y la vascongada de $1982^{19}$.

18 El ser humano es un ser dotado de capacidades pero limitado. De ahí que ciertas aspiraciones no pueda satisfacerlas individualmente pero sí ahondando esfuerzos con otros individuos. Este hecho evidente constituye una de las raíces de la existencia misma del fenómeno societario. Véase J. MiREt Monso, El hombre y sus límites personales, Barcelona, 1949, págs. 8 y sig., Francisco Ayala, Tratado de sociología, Madrid, 1961, págs. 144 y sig. y J. LLUIS y NAVAS, Las bases de la sociedad y el problema social, Barcelona, 1964, págs. 42 y sig.

19 La conclusión de referencias a vagas comunidades entre los objetivos societarios está en relación directa con los orígenes del cooperativismo. En la medida en que tiene consecuencias prácticas, este objetivo ha de ser relacionado con las tendencias confede- 
c) Un caso especial lo constituyen las leyes catalanas que se refieren a los integrantes de las cooperativas y al «entorno»: entorno social en la ley de 1982, entorno comunitario en las de 1992 y 2002.

Es censurable la vaguedad del término «comunidad» que resulta de límites imprecisos y la mayor vaguedad de las referencias al entorno, sea social o comunitario. Esa vaguedad es impropia de la razón de definir que precisamente ha de dirigirse a fijar el alcance de los términos. Por ello mismo la referencia a los beneficios comunitarios la consideramos en este caso impropia de la definición (será cuestión doctrinal que ahora no abordamos su inclusión o no entre los principios y el régimen de deberes). La consideramos impropia de la definición por cuanto en nada contribuye a fijar los perfiles de las sociedades cooperativas. Una vez más ha pesado en esta materia con exceso el doctrinarismo de una de las corrientes del movimiento cooperativo.

I) Gestión democrática. Entre los principios formulados por la $\mathrm{ACl}$ figura el de gestión democrática de las cooperativas. Por esa razón y por razones de política interna casi todas las leyes incorporan esa regla a sus definiciones de las cooperativas, si bien varían ligeramente en su formulación:

a) Se refieren directamente a la gestión democrática la Ley General de 1987 y las de Baleares, catalana del 2002, de Castilla-La Mancha, Extremadura, Galicia, Madrid y Rioja.

b) Establecen el requisito de estructura y funcionamiento democráticos la Ley General de 1999 así como las de Castilla y León y la catalana de 1992.

c) La Ley Catalana de 1983 utilizó la expresión base colectiva que, en este caso, viene a tener un alcance similar al de estructura y por tanto gobierno colectivos.

d) Operan con la idea de gestión colectiva por vía de remisión las leyes navarras de 1989 y 1996 y las vascongadas de 1982

rativas de una parte importante del movimiento cooperativo; pues, a través de las asociaciones de entidades, trata a la vez de satisfacer sus ideales y de obtener ventajas prácticas. De ahí la importancia en el curso de la historia de las medidas sobre las confederaciones cooperativas. Véase BuItrón, Ob. Cit., págs. 201 y sig. y J. LuUIS, «Las variaciones técnicas del encuadramiento orgánico de las cooperativas en Derecho español», Estudios cooperativos, núm. 48 (1978), págs. 22 y sig. 
y 1993 (remisión a los principios), así como la de Aragón (remisión al contenido) y la de Andalucía de 1985 (remisión al contenido y a los principios).

e) Excepcionalmente no entra en la cuestión de la gestión la definición formulada en las leyes valencianas de 1985 y 2003.

El término "gestión democrática» suele ser grato a un importante sector del cooperativismo, el más politizado, y lo recogen los principios de la $\mathrm{ACl}$. De ahí que reaparezca literalmente en un importante grupo de las leyes que nos ocupan. Con todo el empleo de este término no está exento de merecer objeciones: 1. ${ }^{\circ}$ Es un término de origen político y por tanto resulta impreciso tratándose de sociedades de derecho privado, cual las cooperativas. $2{ }^{\circ}$ Si por gestión democrática se entiende gobierno por la colectividad de los socios mejor sería decirlo en estos términos. 3. ${ }^{\circ}$ Por otra parte el gobierno por la colectividad de los socios no es rasgo diferencial pues se da en la mayoría de las formas societarias de carácter privado y asociativo (sociedades mercantiles, asociaciones culturales, etc.). $4 .^{\circ}$ Si lo que se quería establecer es el principio un hombre un voto (principio sobre cuyo alcance no vamos a entrar ahora dados los problemas que plantea especialmente en las cooperativas de producción), mejor hubiera sido decirlo directamente y no mediante expresiones que pueden originar dudas interpretativas.

J) Atribución de resultados. En la raíz misma de los movimientos cooperativistas, particularmente en los que giran en torno a la cooperación de consumo, está la idea de la atribución de resultados económicos en función de las operaciones de los socios. Ello tiene reflejo en las definiciones que nos ocupan del siguiente modo:

a) Establecen como directamente definitoria la regla de distribución de resultados (beneficios) en función de las operaciones realizadas la Ley General de 1987, la gallega y las valenciana de 1985 (tras la reforma de 1995) y del 2003.

b) Otras definiciones lo hacen por la vía indirecta de remisión a los principios. Es el caso de la Ley General de 1999 y de las de Andalucía de 1985, Castilla y León, navarras de 1989 y 1996 y vascongadas de 1982 y 1993.

c) Criterio similar al anterior informa a la ley aragonesa por la vía de remisión al conjunto de su articulado.

d) Las leyes de Baleares, Castilla-La Mancha, las tres catalanas y las de Extremadura, Madrid y La Rioja en el texto de la defini- 
ción de las cooperativas omiten la referencia al reparto de beneficios en función de las operaciones efectuadas.

e) Un supuesto más radical figuraba en la primitiva redacción de la Ley Valenciana de 1985, que excluía todo ánimo de lucro y de reparto de beneficios sociales. No nos sorprende que esta regla desapareciera en la reforma de 1993.

La idea de reparto del resultado de las operaciones (llámesele de beneficios o exceso de percepción) nació en la cooperación de consumo y este dato no es casual. La característica esencial de esa forma de cooperación es la venta a los propios socios. De ahí que optara por la distribución de la diferencia (entre los precios de adquisición de terceros y de suministro a los socios) en función de las compras de cada miembro de la entidad. Pero en su pureza es una norma de difícil aplicación directa a otras formas de cooperación, particularmente a la de producción, a la de elaboración de productos comunes (cooperativas vinícolas y olivareras) así como a las de comercialización de productos de los socios. De ahí que estas formas de cooperación puedan recoger el ideal elaborado en el ámbito del consumo, pero precisen adecuarlo en su aplicación técnica a otros tipos de operaciones. Por esa razón no creemos acertado incluir este rasgo en una definición general que se pretende se corresponda con todas las formas de cooperación 20 .

K) Objetivo de política social. Como consecuencia de sus orígenes ideológicos las definiciones de las cooperativas tienden a incluir expresiones que responden más a los ideales colectivistas (o relativamente

20 Si identificamos la idea de lucro con la de incremento patrimonial se puede poner efectivamente en tela de juicio que algunas formas de cooperación (las que giran en torno a la figura del consumo y de las compras en común) tengan una finalidad lucrativa, aún cuando en todo caso dan lugar a la constitución de empresas. Si recordamos que el lucro consiste en la ventaja patrimonial, toda forma de cooperativa tiene una finalidad lucrativa, por cuanto tanta ventaja patrimonial existe en incrementar beneficios como en reducir gastos. Por otra parte y como destaca Arroyo (Ob. Cit., págs. 17 y sig.), en la polémica sobre el lucro cooperativo no sólo operaba una razón doctrinal; operaba también el interés práctico en la obtención de ventajas fiscales. Pero esto último se debía tan sólo a un error de planteamiento por parte del propio legislador, ya que las ventajas fiscales deberían concederse o negarse en función de un criterio de la utilidad social de determinadas cooperativas, sin entrar en la polémica cuestión de si son lucrativas o no. En todo caso pretender, como insinúan algunos malos doctrinarios, que las cooperativas no producen ventajas económicas (lucro indirecto cuando menos), pero suponen la asunción de un riesgo de empresa, sería lo mismo que tratar de perturbados mentales a todos los socios de las cooperativas y por suerte no es así. 
colectivistas) de un sector importante del movimiento cooperativo. Algunas de estas inclusiones las hemos visto al señalar las anteriores notas de las definiciones contenidas en nuestros sistemas legislativos.

Señalaremos seguidamente otras varias, de difícil clasificación por su misma variedad y que en la mayoría de casos pueden estar justificadas para fijar el fundamento, o los requisititos de las sociedades cooperativas, pero que no siempre contribuyen a fijar el concepto jurídico, es decir, la idea técnica con que se propone operar el legislador.

a) Un importante grupo de definiciones especifican que la empresa que originan las cooperativas es de propiedad conjunta: leyes de Extremadura, Galicia, las Islas Baleares, Madrid y La Rioja. Como variantes de esta formulación señalemos que la ley de Castilla La Mancha utiliza la expresión «empresa conjunta» sin especificar que lo conjunto es su propiedad; en cambio las leyes valencianas emplean el término "empresa común», que también utiliza el legislador navarro de 1989 y 1996 («empresa en común»). En cambio las leyes catalanas sustentan que sea la empresa, sea su actividad es "de base colectiva».

Las leyes generales de 1987 y 1999, así como las de Aragón, Andalucía, de 1985, la de Castilla y León y las vascongadas de 1982 y 1993, incluso cuando se refieren a la empresa, evitan calificarla de común. Lo cierto es que toda empresa es propiedad de sus titulares, constituyan estos una sociedad o una agrupación sin personalidad jurídica, por lo cual el carácter colectivo (limitado a los titulares) no es nota diferenciadora de las empresas creadas por cooperativas o por sociedades mercantiles clásicas.

b) Con variantes en su formulación, varias de las leyes que estamos estudiando recogen la idea de mutua ayuda entre los socios, objetivo que tampoco es exclusivo de las cooperativas aun cuando sí es una aspiración al cooperativismo y que nuestras legislaciones expresan de diversos modos: 1. ${ }^{\circ}$ Unas disposiciones se refieren a la satisfacción en común de las necesidades de los integrantes de las cooperativas (Ley General de 1987 y con más precisión leyes de Aragón, Baleares, Castilla y León, Extremadura, Galicia, La Rioja y Madrid, y de modo más barroco las tres leyes catalanas). 2. ${ }^{\circ}$ Especifican que las cooperativas están al servicio de sus miembros (o si se prefiere operan con la idea de autoservicio) la Ley General de 1987, la andaluza de 1985 y las de Castilla-La Mancha, las tres catalanas, la de Gali- 
cia, las navarras de 1989 y 1996, la reforma valenciana del 2003 así como la reforma de 1995 y la vascongada de 1982 y 1993. 3. ${ }^{\circ}$ Adicionan la idea de servicio a la comunidad, la Ley General de 1987 y las de Andalucía de 1985, Castilla-La Mancha, las tres catalanas (estas mediante referencia al "entorno»), Galicia, la valenciana de 1985 (que tras la reforma de 1993 redujo la idea de servir a la Comunidad a la de atender a la Comunidad del entorno; y suprimió la referencia a la comunidad en el texto del 2003); las leyes navarras de 1989 y 1996 también se remiten al interés de la comunidad; y en cuanto a las vascongadas, la de 1982 se refiere al servicio de la comunidad y la de 1993 sólo considera que se atiende a la comunidad. Ello refleja una gran variedad en el grado en que los legisladores han considerado que la actividad cooperativa ha de vincularse a los intereses comunitarios. $4 .^{\circ}$ Adicionan la idea de mutua ayuda entre los socios la ley andaluza de 1985 las tres catalanas (que utilizan la expresión "servicio mutuo») y todas las valencianas.

c) Asimismo algunas de las leyes que nos ocupan incluyen en las definiciones referencias a la distribución de los resultados (beneficios) conforme a criterios cooperativistas y por tanto excluyendo los de carácter capitalista. Imputan los resultados económicos en función de la actividad cooperativa de la Ley General de 1987, las de Galicia y las valencianas de 1993 y 2003 (la de 1985 pretendía excluir el ánimo de lucro y los beneficios sociales). Naturalmente llegan a la misma conclusión las leyes cuyas definiciones hemos visto se remiten sea al contenido del articulado de la ley, sea a los principios del cooperativismo ${ }^{21}$.

d) Algunas leyes recogen la idea de actividad de los propios socios en relación con la función cooperativa. Es el caso de la ley andaluza de 1985, la del País Vasco de 1993, la Gallega de 1998 e implícitamente de las que fijan la distribución de los beneficios en función de la actividad cooperativizada de cada socio (caso de la Ley General de 1987, de las valencianas de 1995 y 2003), las tres catalanas parecen interpretables en el mismo sentido aún cuando su barroquismo dificulta su interpretación racional.

e) Las tres leyes catalanas tienen aditamientos líricos, impropios de una definición jurídica que hacen dudar de los conocimien-

21 Véase la nota 14. 
tos legales (por no decir otras cosas) de sus redactores. Así, según las tres leyes es definitorio de las cooperativas la mejora de las relaciones humanas y la anteposición de los intereses colectivos «por encima de toda idea de beneficio particular». Nos preguntamos si los redactores de tales afirmaciones conocen la diferencia entre el ser (en cuya fijación ha de centrarse toda definición) y el deber o querer ser (que ha de determinarse mediante su régimen obligacional).

\section{Naturaleza}

Frente a la diversidad de formulaciones del concepto de cooperativa destaca la unanimidad, por la vía indirecta, de las leyes que estamos estudiando en lo que se refiere a la naturaleza jurídica de las cooperativas. En efecto, todas estas disposiciones tienen en común:

a) Carecen de un precepto directamente dirigido a fijar la naturaleza de las cooperativas.

b) Del articulado de todas ellas resulta que constituyen sociedades de naturaleza privada en el sentido de constituir agrupaciones organizadas de personas, establecidas mediante pacto y de naturaleza privada, es decir, sin participar en el poder de imperio de los poderes públicos.

c) Asimismo de todas ellas resulta que son entidades de finalidad económica (o si se prefiere económico-social)

d) Finalmente todas ellas son sociedades «sui generis» en el sentido de que están sometidas a regulación propia y específica (las correspondientes leyes de cooperativas) ${ }^{22}$.

Refuerza la naturaleza especial, desde un punto de vista positivo, la comunidad de principios informantes de nuestras diversas leyes de cooperativas, comunidad atribuible al peso de las posturas de la A.C.I. sobres los redactores de los diversos textos legales ${ }^{23}$.

22 Como advierte Arroyo (Ob. Cit., pág. 17), la atribución (desde el punto de vista positivo) de naturaleza especial venía requerido por el sistema constitucional para la transmisión a las entidades autónomas de la facultad legislativa en materia cooperativa, pues en materia mercantil y social la legislación es común.

23 Los principios inspirados en los ideales de los orígenes de la cooperación están en relación directa con los objetivos de política social del movimiento constitucionalista y con lo que pudiéramos llamar constitucionalización del derecho cooperativo. Véase Alberto GARCía MulleR, «La economía del trabajo social o solidaria en las constituciones de América Latina», Anuario de Estudios cooperativos, (1994), pág. 75. 
e) Estamos ante disposiciones que en general evitan pronunciarse sobre la naturaleza lucrativa o no de las cooperativas. Solo excepcionalmente la ley valenciana de 1982 les atribuyó esa condición. Pero la ley fue reformada en 1995 y la de 2003 participa del propósito de evitar entrar en esa cuestión. El carácter polémico de la cuestión de la naturaleza lucrativa de las cooperativas explica que los legisladores optaran por no pronunciarse. Por nuestra parte ya hemos destacado en otra ocasión ${ }^{24}$ que la tesis de la naturaleza extralucrativa de las cooperativas dimana una vez más del peso de las entidades de consumo en el origen de las antiguas doctrinas de un sector cooperativista; que en ningún caso se puede pretender que las de ventas en común, trasformación de productos agrícolas, etc., carezcan de finalidad lucrativa en el sentido de incremento patrimonial; y finalmente las de consumo también tienen un objetivo lucrativo en el sentido de atenuación de las reducciones de patrimonio (al conseguir adquirir en mejores condiciones económicas).

\section{Denominación}

A) Reglas comunes. Los sistemas legales sobre entidades societarias establecen, en general de modo expreso, dos reglas: $1 .^{\circ}$ La entidad ha de tener un nombre que evite confundirla con otra. $2 .^{\circ} \mathrm{El}$ nombre de la entidad ha de reflejar su naturaleza (en nuestro caso que se trata de una cooperativa $)^{25}$. Dada la finalidad identificativa de las denominaciones, entendemos que incluso cuando esta exigencia no se establece de modo expreso, opera de modo tácito, por exigirlo un principio de buena fe en las relaciones humanas. La denominación es un medio esencial para determinar los respectivos titulares de derecho, deberes y responsabilidades. De ahí que constituyan una función jurídica, es decir, a la vez un derecho y un deber que recae sobre cada entidad en lo que le beneficia y en lo que le pudiera suponer una carga para cumplir sus obligaciones y asumir sus responsabilidades. De ahí también que todas las leyes actuales, tanto la general como las territoriales exijan consignar en el nombre la condición cooperativa de la entidad, al menos con la abreviatura S. Coop.

24 Véase la nota 20 y J. LLuIs, Derecho... T. ${ }^{\circ}$, págs. 56 y sig.

25 López-Nieto, Ob. Cit., pág. 223 y N. Paz, Ob. Cit., pág. 80. 
En cambio las diversas leyes que nos ocupan divergen en cuanto a otros dos elementos de la denominación.

B) Indicación del grado de responsabilidad. Respecto de la obligatoriedad o no de consignar si la cooperativa es de responsabilidad limitada o ilimitada, advertimos las siguientes variantes:

a) La mayoría de las legislaciones que nos ocupan, incluso las Leyes Generales de 1987 y 1999 no exigen incorporar a la denominación de la cooperativa la indicación del tipo de responsabilidad.

b) Sí lo exigen las tres leyes catalanas de 1983, 1993 y 2002. Un caso relativamente particular lo ofrece la legislación valenciana de 1985 y 2003 que dispone que en caso, de ser la responsabilidad ilimitada, deberá constar en la denominación, lo que a sensu contrario implica que las que nada indican son de responsabilidad limitada.

c) Un caso especial lo constituye el legislador vasco pues la ley de 1982 disponía que se indicara el tipo de responsabilidad y la ley de 1993 ha dejado de establecer ese requisito.

C) Indicación de adscripción territorial. Advertimos que en el conjunto legislativo cooperativo se dan las siguientes variantes:

a) Disposiciones que exigen conste en la denominación de las respectivas cooperativas su adscripción regional: leyes andaluza de 1985, Castilla-La Mancha, las tres catalanas de 1983, 1992 y 2003, las de Galicia, Madrid y de Valencia de 1985 y 2002.

b) Sistemas legislativos que autorizan se consigne la regionalidad, pero sin exigirlo: leyes de Aragón y de Castilla y León.

c) Sistemas que no contemplan la eventual consignación de la adscripción regional (aún cuando por el principio de libertad de lo no prohibido tienen el mismo efecto práctico que las del grupo precedente). Están en este caso las leyes de Baleares, Extremadura, navarras de 1989 y 1996, riojana y vascongadas de 1982 y 1993.

La primera en el tiempo que exigió la conspiración de la adscripción territorial fue la ley catalana de 1983. Probablemente se acordó así como una afirmación de particularismo. No obstante los preámbulos de la ley gallega de 1998 y de la de Castilla-La Mancha exponen una doble razón para exigir esta solución: una razón es política (asegurar consta la «identidad» de la cooperativa) la otra es jurídica (asegurar conste el régimen 
legal a que está sometida). Sobre el primer motivo nada diremos pues no deseamos entrar en cuestiones políticas en este trabajo. Respecto del segundo, efectivamente, dada la variedad de normativas a que actualmente se ven sometidas las sociedades cooperativas, la consignación de su regionalidad, sin ser imprescindible, puede resultar tan útil como la indicación de su grado de responsabilidad.

\section{Domicilio}

Todas nuestras leyes sobre cooperativas tienen en común: $1 .^{\circ}$ Atender al problema de la determinación del domicilio; $2 .^{\circ}$ Exigir que las cooperativas sometidas a su normativa estén domiciliadas dentro de su respectivo territorio: el territorio nacional en el caso de las sometidas a la Ley General, el correspondiente territorio regional en el de las sometidas a la normativa autonómica.

En cambio se acusan variantes cuando se trata de especificar el lugar de ubicación dentro de las indicadas áreas territoriales.

a) Un sistema de libertad (relativa) de elección del domicilio lo aplican las leyes de Baleares, Castilla-León y navarras de 1989 y 1996, pues dejan escoger el domicilio dentro del ámbito de sus respectivos territorios. Las de Baleares y Castilla-León añaden que la sede administrativa radicará igualmente en su territorio, pero no exigen que ésta coincida con el domicilio.

b) El sistema contrario, de domicilio necesario, lo siguen las leyes catalanas de 1983, 1992 y 2002 pues obligan a que el domicilio radique precisamente en el lugar donde radique su actividad económica y social. La determinación de qué actividad se trata puede ofrecer alguna duda, aun cuando parece que deberá tratarse de la actividad económica principal, dado que los textos catalanes se refieren a la actividad «económica y social».

c) La mayor parte de las legislaciones que nos ocupan adoptan un sistema optativo dualista (o si se prefiere optativo restringido) pues facultan para optar entre la sede de la Gerencia y la de la actividad de la entidad. Con todo se registran variantes en la forma como se determina la actividad contemplada por los respectivos legisladores. En efecto: 1. Especifican que ha de tratarse de la actividad principal la Ley General de 1999, la de Madrid y las valencianas de 1985 y 2003 (la fórmula utilizada es donde realicen «principalmente» sus actividades según la 
ley madrileña y las valencianas y «preferentemente» según la ley general de 1999). 2. ${ }^{\circ}$ Especifican que la actividad preferente ha de efectuarse con los socios la Ley General de 1987 y las autonómicas de Aragón, Andalucía, Extremadura y vascongadas de 1982 y 1983. 3. ${ }^{\circ}$ Especifican que la actividad determinante del lugar de elección del domicilio es el de realización «principalmente» de la actividad cooperativizada las leyes de Castilla-La Mancha y de Galicia. 4. ${ }^{\circ}$ Una ligera variante de la anterior la presenta la ley de La Rioja que se refiere a la actividad «económica y social» desarrollada principalmente con los socios; o sea, se refiere muy concretamente a la actividad cooperativizada pero sin utilizar ese término. Consiguientemente, podemos concluir que, dentro del grupo dualista, las consecuencias prácticas de sus diferencias son de escaso alcance, que estamos más ante variantes de modo de expresión que ante diferencias realmente sustanciales.

\section{Los principios cooperativos}

A) Sistemas generales. Si contemplamos el conjunto de la legislación española, tanto actual como histórica, advertimos que los principios jurídicos se determinan de dos modos: 1. ${ }^{\circ}$ En algunas disposiciones se formulan de modo expreso: caso de las Partidas, de la ley sindical franquista de 1971 (art. 4) etc.; es con mucho el sistema más infrecuente aun cuando en materia cooperativa es el más generalizado ${ }^{26} .{ }^{\circ}{ }^{\circ}$ En la mayoría de los casos los principios informantes operan de modo implícito (Código Penal, Ley de Enjuiciamiento Civil, etc.).

Por lo que se refiere al derecho cooperativo del período que nos ocupa, podemos advertir las siguientes soluciones:

a) Leyes que enumeran los principios que pretenden aplicar. Dentro de ellas existen dos subgrupos claramente diferenciados: 1. ${ }^{\circ}$ Disposiciones que tratan los principios como elemento definidor y por tanto forman parte de su definición de las cooperativas, es el caso de las leyes andaluza de 1985, navarra de 1989 y vascongada de 1982. 2. ${ }^{\circ}$ Leyes que tratan los principios como elemento informante de la normativa cooperativa, y por

26 Sobre la relación entre los principios cooperativos y la constitucionalización del Derecho cooperativo véase García MulLeR, Ob. Cit., págs. 74-76. 
tanto no los incluyen en la definición; es el sistema seguido por la ley balear, las catalanas de 1983 y 1992 y las valencianas de 1985 y 2003.

b) Leyes que contienen una referencia global a los principios cooperativos pero evitando enumerarlos. También en este caso existen los dos subgrupos señalados en el párrafo anterior, a saber: $1 .^{\circ}$ Tratan de los principios (que no enumeran) como elemento definidor la Ley General de 1999, la vascongada 1993, la de Navarra de 1996 y la de Castilla y León del 2002. 2. Se refieren a los principios como elemento informante la Ley General de 1987 y las de Aragón de 1998, Castilla-La Mancha de 2002, catalana del mismo año, extremeña de 1998, gallega de 1998, madrileña de 1999 y riojana del 2001.

Hemos de destacar que estas agrupaciones no concuerdan con los partidos en el poder en el momento en que se promulgaron las disposiciones acabadas de señalar. Por tanto las diferencias que implican no parecen atribuibles a posturas políticas.

C) Forma de vinculación a los principios de la Alianza Cooperativa. La influencia política de la $\mathrm{ACl}$ en el mundo cooperativista ha sido, para bien o para mal, lo suficientemente fuerte como para dar lugar a que los principios formulados por la Alianza hayan informado todas las leyes actuales sobre cooperativas. No obstante varía la forma como nuestros legisladores se vinculan a las mismas, pudiendo destacar las siguientes variantes:

a) Sistemas que enumeran los principios y en el propio articulado advierten que son los de la $\mathrm{ACl}$.: leyes de Baleares y valencianas de 1985 y 2003.

b) Leyes que enumeran los principios sin indicar en el articulado que son de la ACl: leyes de Andalucía de 1985, catalanas de 1983 y 1992, Navarra de 1989 y vascongada de 1982; es de advertir que, con ciertas salvedades respecto de las catalanas, estas disposiciones recuerdan en sus preámbulos que están aplicando los principios de la $\mathrm{ACl}$.

c) Disposiciones que se remiten a los principios del cooperativismo sin indicar en su articulado que son los de la ACl (aun cuando los consignan en el preámbulo): leyes vascongada de 1993 y de Extremadura.

d) Proceden a una remisión global (sin enumeración) a los principios de la $\mathrm{ACl}$, pero con la restricción de que quedan recogidos en la forma que resulta de la propia ley las generales de coope- 
rativas de 1987 y 1999, y las de Aragón, ambas Castillas, Galicia, Madrid, Navarra de 1996 y La Rioja. Esta remisión la efectúan en el articulado y algunas (Castilla-La Mancha, Madrid, Rioja) la reiteran en el Preámbulo.

e) Un caso particular y poco feliz lo constituye la ley catalana del 2002 que, además de remitirse globalmente a los principios de la $\mathrm{ACl}$ sin enumerarlos, les atribuye formalmente fuerza de criterio de interpretación de la legislación cooperativa del Principado. Por tanto todas las leyes que nos ocupan se remiten a la $\mathrm{ACl}$ pero formalmente en grado distinto. Los principios jurídicos ejercen una triple función: informar, justificar e interpretar y suplir la leyes positivas. Por tanto atribuir a una entidad extranjera la facultad de formular directamente reglas vinculantes, como hace la ley catalana, nos parece inadmisible doctrinalmente además de contrario a la soberanía estatal e incluso al Estatuto de Autonomía. Incluso nos parece censurable la remisión directa a los principios de la $\mathrm{ACl}$ aun cuando sea con la reserva del grado en que los recoge nuestra legislación.

\section{Derecho interterritorial}

\section{Indicación general}

La existencia de una Ley General y de diversas leyes regionales en materia cooperativa plantea el problema de posibles conflictos en la determinación del ordenamiento (general o regional) aplicable; o sea, nos pide la fijación de las normas de derecho interterritorial. La Ley General de Cooperativas de 1987 carecía de una disposición que solucionara el problema. La de 1999 contiene una solución (art. 2) pero insuficiente, por lo que será preciso acudir a otras disposiciones particularmente el Código Civil (arts. 8 a 12, rectificados por los arts. 13 a 16), pero completándolos con la legislación cooperativa y analizando los problemas que las normas del Código plantean al relacionarse con la normativa cooperativa ${ }^{27}$.

27 Incluso concentrándonos en la legislación estatal contrasta la continuidad y estabilidad del Derecho argentino con las grandes variaciones registradas en el nuestro. Sólo en el último cuarto de siglo han regido en España tres leyes generales de cooperativas, las de 1974, 1987 y 1999. Véase Jaime LLUIS Y NAVAS, «Las orientaciones generales y orgánicas del Derecho cooperativo en Argentina y España», en la Ob. Col. Estudios de Derecho Civil en Homenaje al Dr. LluIS MoISSET DE ESPANES, Buenos Aires, 1980, págs. 773 y sig. 
2. Supuestos de aplicación de la legislación estatal

A) Aplicación directa de la Ley General. Entendemos que la Ley General de Cooperativas es de aplicación directa en los siguientes supuestos:

a) Por razón de la actividad se aplicará la Ley General a las cooperativas que desarrollen su actividad cooperativizada en territorio de varias regiones, salvo si sólo en una de ellas se actúa con carácter principal (art. 2 de la Ley General de 1999). Esta disposición pide varias precisiones: $1 .^{\circ}$ Establece un distingo entre cooperativas que actúan en una sola región (en cuyo caso están sin duda sometidas a la normativa de su territorio), en varias con carácter principal en una determinada (en cuyo caso también están sometidas en principio a la norma de su actividad principal, aun cuando, como veremos, se plantea el problema de la norma reguladora de los actos en otro territorio) y cooperativas sin actividad principal en un territorio determinado (en cuyo caso se rigen por la Ley General). 2. ${ }^{\circ}$ Los supuestos acabados de exponer piden una regla determinante de cómo se fija la actividad principal; en parte este problema lo resuelve el Reglamento del Registro de Cooperativas (R.D. 136/02), cuyo art. 2.2 establece que inicialmente el territorio de su actividad principal "se deducirá de sus Estatutos» y como regla objetiva establece que se considerará que la actividad principal está circunscrita a un determinado territorio cuando la actividad en él realizada «sea superior a la realizada en el conjunto de los demás territorios», lo que dista de despejar todas la dudas, por ejemplo si en un territorio se hace el mayor número de operaciones y en otro las de mayor volumen económico. $3 .^{\circ}$ La indicada regla implica que una alteración del volumen de operaciones en un lugar determinado (un cambio de clientela en las cooperativas de producción o de comercialización agrícola, un cambio de suministradores en las de consumo) exponga a acarrear la modificación de la normativa a que se ve sometida la cooperativa. 4. ${ }^{\circ}$ Las entidades de grado mayor (cooperativas de segundo y tercer grado, Federaciones, etc.) tendrán naturaleza regional o interregional según agrupen o no a entidades de uno o varios territorios, puesto que, de pertenecer sus miembros a más de uno, la actividad principal pasa a ser interregional, dada la función federativa y de servicios a las entidades agrupadas que ejercen las de grado mayor. 
b) Por razón del territorio la Ley General se aplicará en Ceuta y Melilla (art. 2 de la Ley de 1999).

c) También se aplicará la Ley General en los casos en que lo pida el art. 149 de la Constitución por tratarse de materias consideradas básicas.

d) Entendemos que la legislación cooperativa general se aplicará asimismo en caso de producirse un vacío legislativo, lo que podría obedecer a que una región se abstiene de legislar en materia cooperativa o a que deroga su propia legislación sin promulgar norma sustitutoria (supuesto por otra parte altamente improbable). En efecto ante el vacío legislativo sería preciso recurrir a la analogía y extender a los territorios carentes de norma la regla sobre Ceuta y Melilla pues evidentemente operaría la identidad de razón requerida en el art. 4 del Código Civil. Plantean este problema Asturias, Canarias, Cantabria y Murcia. A la misma conclusión nos lleva el art. 149 de la Constitución de 1978 puesto que dispone que el derecho estatal es supletorio del autonómico.

B) Normativa de solución de conflictos territoriales. Entendemos que para determinar en caso de conflictos qué ordenamiento ha de aplicarse, ello deberá hacerse a tenor de la legislación estatal por las siguientes razones:

a) Recordemos que una cooperativa con vecindad regional puede efectuar actos (no principales) fuera de su territorio. En tal caso la normativa aplicable la determina la legislación estatal por lo mismo que ninguna autoridad regional puede pretender tener autoridad sobre otra (ni los respectivos estatutos de autonomía les atribuyen tal competencia) ya que las diversas regiones autónomas no están subordinadas entre sí.

b) Por otra parte, en la razón de ser de las autoridades generales, incluso en los Estados Federales, figura resolver los conflictos entre los miembros de la Unión a fin de asegurar la convivencia pacífica con un criterio de justicia.

c) Por cuanto el propio Código Civil (arts. 13 a 16 principalmente), al fijar las normas de solución de conflictos interterritoriales, está consagrando que estamos ante una función estatal.

C) Reglas generales sobre conflictos de normas. Entendemos que operan las siguientes:

a) La calificación de los actos jurídicos, sean de derecho general, sean de derecho cooperativo, así como la determinación de 
qué actividad ha de considerarse cooperativizada y la distribución territorial de su volumen habrán de efectuarse de conformidad con la legislación general, a efectos de determinar la normativa a que se ve sometida una entidad cooperativa. Así lo pide el art. 12 del Código Civil y lo confirma la regla sobre inexistencia de relación jerárquica entre autoridades autónomas regionales. Ello no es óbice para que la decisión de la autoridad estatal (o sea del Ministerio de Trabajo) sea recurrible en vía judicial (ordinaria y eventualmente constitucional).

b) La legislación sobre conflicto de normas se aplicará de oficio, visto el art. 12.6 del Código Civil. Claro que ello no es óbice para que también pueda ser solicitada a petición de parte interesada y por tanto a petición tanto de las autoridades centrales como de las regionales. Esta norma alcanza tanto a los procedimientos judiciales como a los administrativos. Por tanto la Inspección de Trabajo (vista la Ley de Inspección 42/97, art. 3) está facultada para promover expedientes de cambio de la asignación de vecindad civil a una cooperativa.

c) Por ser cuestión de derecho interno español no cabe la excepción de orden público (art. 16 del Código) entre ordenamientos jurídicos hispanos. Por tanto en caso de querer impugnar el contenido de alguna ley de cooperativas sería preciso recurrir a otra vía, fundamentalmente la constitucional.

d) En cambio si procederá, en su caso, la excepción de fraude a la ley ${ }^{28}$, visto el art. 6.4 del Código Civil y habida cuenta de que el fraude a la ley supone la corrección de las normas y la incorrección en el modo de servirse de ellas.

e) Queda excluida la doble regionalidad. Más exactamente la doble regionalidad (por causa de desarrollar la actividad principal en más de una comunidad autónoma) da lugar al cambio de la normativa aplicable (aplicación directa de la Ley General; art. 2 de dicha Ley). Incluso haciendo abstracción de la norma específicamente cooperativa el Código Civil nos llevaría a la misma conclusión. En efecto, el art. 14 del Código excluye la doble vecindad civil para las personas físicas y por analogía (art. 4 del Código) la misma regla habría que aplicar a las jurídi-

28 Véase Antonio Rodríguez Arados, «El fraude de la ley», en la Ob. col. El Título Preliminar del Código Civil, T. ${ }^{\circ}$ I, vol. $1 .^{\circ}$, pág. 316 y J. LLUIS y NAVAS, «El fraude de ley ante el derecho interno de los Estados», Revista general de Legislación y Jurisprudencia, (1957), págs. 57 y sig. 
cas, al existir identidad de razón y también por aplicación del principio que informa el art. 14.

Las diversas leyes de cooperativas confirman la exclusión de la doble regionalidad al vincular la condición regional a las operaciones principales y a la residencia de sus órganos rectores en el territorio a que están adscritas las respectivas sociedades cooperativas. Esta confirmación aún es más notoria en los sistemas que exigen consignar la naturaleza regional en la denominación de la entidad (leyes de Andalucía, Castilla-La Mancha, las tres catalanas, Galicia, Madrid y Valencia) o cuando menos lo autorizan formalmente (leyes de Aragón y Castilla y León).

\section{Normas estructurales}

A falta de un término mejor damos esta denominación a las reglas referidas a la estructura esencial de las entidades cooperativas (constitución, domicilio, etc.) que operan incluso haciendo abstracción de los actos jurídicos concretos que efectúen las cooperativas en el curso de su actuación.

A) Principio general. El art. 2 de la Ley de Cooperativas de 1999, como ya hemos visto, establece que las cooperativas que desarrollan su actividad principal en más de un territorio están sometidas a la Ley General de Cooperativas. A sensu contrario ello significa que aquéllas cuya actividad principal se circunscribe a un solo territorio están sometidas a la normativa del mismo. Esta regla encierra un principio general (con el valor que el art. 1 del Código Civil atribuye a los principios) que informa todo el sistema. Con todo creemos necesario formular algunas precisiones.

B) Constitución. Dado lo dispuesto en el art. 2 de la Ley de Cooperativas de 1999, con las precisiones desarrolladas en el Reglamento del Registro proceden estas distinciones: $1 .^{\circ}$ La constitución de cooperativas se rige en España por el principio de nacionalidad (art. 9.11 del Código Civil) y por tanto las constituidas en España tienen nacionalidad española y se rigen por la legislación española, o sea por la Ley General de Cooperativas, y en su caso por las leyes regionales. 2. ${ }^{\circ} \mathrm{Si}$ la actividad atribuida a la cooperativa es de carácter interregional sin actividad principal en un determinado territorio español, se constituirá según las normas de la Ley General (art. 2). 3. ${ }^{\circ}$ En el improbable caso de que se constituyera en España con el propósito de desarrollar su actividad principal en el extranjero, también se constituirá de confor- 
midad con la Ley General al no existir territorio regional que por razón de la actividad atraiga la regulación de la cooperativa (art. 2 de la Ley General). $4 .^{\circ}$ Si tienen la actividad principal centrada en una determinada región deberán constituirse de acuerdo con la normativa promulgada en la misma (art. 2) y en defecto de norma regional subsidiariamente por la Ley General.

Confirman lo indicado: $1 .^{\circ}$ los diversos estatutos de autonomía en cuanto que atribuyen a las respectivas instituciones autónomas la facultad de legislar en materia cooperativa y por tanto la de regular la constitución de las sociedades cooperativas. Ello es así tanto si esa facultad se atribuyó en los estatutos iniciales (caso de Andalucía, Cataluña, Galicia, Navarra, País Vasco y Valencia), como si la atribución ha sido objeto de reforma de los estatutos originales (caso de las restantes comunidades autónomas, excepto Ceuta y Melilla, en que la facultad de legislar en materia cooperativa fue atribuida en bloque en 1994, mediante las Leyes Orgánicas 1 a 11 de 1994). 2. ․ Confirman lo indicado la totalidad de las diversas leyes regionales de cooperativas en cuanto que, en función de los criterios de adscripción que hemos visto, vienen a disponer que las sociedades cooperativas que se constituyan en sus respectivos territorios lo hagan bajo la respectiva legislación local; esta regla operaba incluso bajo la Ley Vasca de 1982 (arts. 6 y 7) aun cuando su redacción ofrecía a este respecto alguna oscuridad, subsanada en la ley de 1993. 3.․ La misma solución pediría un principio de racionalidad interpretativa (en base al art. 3 del Código civil), pues si el legislador estatal autoriza a determinados (por no decir a todos) territorios para disponer de una normativa cooperativa propia, y las autoridades autónomas regulan la constitución de las cooperativas en sus respectivos territorios, es evidente que la constitución de las cooperativas ha de efectuarse ordinariamente de conformidad con lo dispuesto en la legislación aplicable en el lugar en que se constituyen (con las excepciones que puedan resultar de la exclusión de la normativa regional por no haber promulgado la legislación propia, por no figurar la normativa cooperativa entre las atribuciones o por tratarse de entidades que por la dispersión de su actividad no resultan adscribibles a un territorio determinado) ${ }^{29}$.

C) Estatutos sociales y domicilio inicial. Como regla general la sede inicial de las cooperativas españolas ha de radicar en territorio

29 Véase Montolıo, Ob. Cit., pág. 31 y Arroyo, Ob. Cit., págs. 12 y sig. 
español y precisamente en la región en que se constituyó la entidad y asimismo sus estatutos sociales se ven regulados por la correspondiente normativa española (sea estatal o regional). La sumisión a la normativa española viene requerida por el art. 9.11 del Código civil y respecto de los estatutos sociales la corrobora el art. 11.2. Esta normativa se ve confirmada por la Ley General de Cooperativas de 1999, tanto a efectos de ubicación del domicilio (art. 4) como de regularización de los estatutos sociales (regla implícita en los arts. 7 a 11 de la Ley de 1999).

Confirman lo acabado de indicar las diversas leyes regionales de cooperativas pues todas ellas requieren que las entidades sometidas a su normativa se hallen asimismo domiciliadas en su territorio. No obstante podemos hacer una distinción respecto de la perfección técnica con que se establece la vinculación domiciliar, señalando dos grandes grupos de normas: $1 .^{\circ}$ las leyes de Baleares, Castilla y León y navarras de 1982 y 1996 adoptan un sistema de regla específica a tenor del cual el precepto que requiere que las cooperativas sometidas a su legislación radiquen en su territorio carece de aditamentos (caso de las normas navarras) o éste se limita a especificar que en el domicilio han de radicar los órganos de gobierno (leyes castellanoleonesas y balear); por tanto la norma resulta de absoluta claridad. 2. ${ }^{\circ}$ las restantes leyes adoptan un sistema de síntesis de dos reglas en un mismo precepto; una de estas normas es de derecho interterritorial (la obligación de domiciliarse en el propio territorio) y la otra es de derecho interno (la obligación de escoger para domicilio, sea la localidad de las operaciones principales (criterio de las leyes catalanas de 1983, 1992 y 2002) sea fijando una facultad de opción entre las localidades de las operaciones principales y la ubicación de la gerencia (leyes de Andalucía, Aragón, Castilla-La Mancha, Extremadura, Galicia, Madrid, Rioja, así como las vascongadas y valencianas). El defecto técnico de implicar la norma interna y la interterritorial arranca del art. 3 de la Ley General de 1987.

Las diversas leyes de cooperativas regulan el contenido de los estatutos sociales de las entidades sometidas a la respectiva ley, dentro del cual fijan el domicilio como hemos visto. Corroboran así que la vecindad civil determina la normativa aplicable sobre estatutos sociales.

D) Cambios de domicilio social. Las modificaciones del domicilio en el seno de una misma región son cuestión de derecho interno. Por el contrario las modificaciones de ubicación que suponen modificar la región de residencia principal afecta al derecho interterritorial. 
Los cambios domiciliares pueden ser voluntarios o forzosos, según obedezcan a una decisión de la propia cooperativa o a una imposición del legislador. En ambos casos ha de relacionarse con el eventual cambio del centro principal de actuaciones (visto el art. 2 de la Ley General de 1999), pues la Ley General dispone que las cooperativas han de residir en la región de su actividad principal. Por tanto el lugar de la actividad principal operará como requisito de la modificación del domicilio y si se produce ese cambio de centro de actividad, la modificación del domicilio pasará a constituir una obligación. En todo caso seguirá operando la regla de determinación de la región de ubicación del domicilio en función de la actividad principal.

E) Modificación de los estatutos sociales. Las modificaciones que no supongan cambio de región de residencia se regirán naturalmente por la ley del lugar donde radiquen las respectivas cooperativas.

En cambio, las que impliquen radicar en otro domicilio, además de requerir satisfacer el ya referido requisito de concordancia con el centro principal de operaciones, deberán satisfacer tanto la normativa del territorio de origen como la del de residencia. Lo primero para que el acuerdo sea lícito y lo segundo para que sea válido en el nuevo lugar de establecimiento.

F) Fusión de cooperativas. Si las cooperativas que se proponen fusionarse están sometidas a ordenamientos distintos, los acuerdos de fusión habrán de satisfacer los requisitos de ambos ordenamientos, ya que estamos ante ordenamientos igualmente amparados en nuestro sistema político y por tanto a estos efectos ninguno de ellos está subordinado al otro. Además, es la solución que pide el art. 9.11 in fine del Código civil. La entidad resultante de la fusión estará sometida al régimen del nuevo domicilio que vendrá determinado por la actividad principal y si éste fuere interregional pasará a verse directamente sometida a la Ley General de 1999 (art. 2), por lo que la fusión y el estatuto social común habrán de satisfacer asimismo los requisitos de la Ley General.

G) Sucursales. Las cooperativas domiciliadas en un determinado territorio español pueden en principio establecer delegaciones y sucursales en cualquier otro. Es incluso el supuesto normal de algunas cooperativas (de comercialización de vinos y otros productos agrícolas, de fabricación de electrodomésticos, etc.). En esos casos, si el volumen de las sucursales es tal que la actividad principal queda difumina- 
da, las cooperativas pasarán a verse sometidas a la Ley General. En caso contrario, o sea, si la actividad principal sigue desarrollándose en la sede central, el régimen interior cooperativo de las sucursales (constitución, funcionamiento interior, etc.) se regirá por la normativa aplicable a la sede central (domicilio) de la cooperativa visto en el art. 9.11 del Código civil. Cuestión distinta son los actos de relación con tercero a lo que seguidamente nos referiremos.

H) Representación. Entendemos que se regirá por las normas aplicables a la vecindad civil y domicilio de la cooperativa, tanto si son de derecho cooperativo como de derecho civil foral, aplicando el art. 9.11 del Código Civil que entendemos ha de prevalecer sobre el ¿?, 11 por ser el primero de estos preceptos específicos para las personas jurídicas.

\section{Normativa funcional}

Agrupamos en este apartado las reglas referidas al funcionamiento de la entidad, a los actos y negocios jurídicos que desarrolla.

A) Capacidad de las sociedades cooperativas. La capacidad de las cooperativas para formular negocios jurídicos, sea internos (modificación de Estatutos, nombramientos de Rectores, etc.), sea externos (contratos, actuaciones unilaterales, etc.) se rigen por la ley correspondiente a la vecindad civil de la persona jurídica (art. 9.11 del Código Civil); ya hemos visto que, en el caso de las cooperativas, la regionalidad ha de coincidir con su domicilio social.

B) Forma de los actos jurídicos. A la vista del art. 11.1 del Código Civil operará la facultad de opción entre las siguientes eventualidades: utilizar la forma exigida en el lugar de otorgamiento, la del lugar que pida el contenido del acto, la correspondiente a la sede de la cooperativa disponente y, tratándose de contratos sobre inmuebles, la del lugar donde éstos radiquen. Esta facultad alcanza tanto al ordenamiento cooperativo como al civil común y foral. Entendemos que cabe la opción expresa y la tácita (visto el art. 1.278 del Código Civil) y que la opción tácita por una determinada forma resulta de la aplicada al suscribir el acto jurídico ${ }^{30}$.

30 Utilizamos los términos actos y negocios jurídicos en el sentido que los utiliza la doctrina española, distintos de su empleo en Hispanoamérica. Véase LuIs MoIsSET DE ESPA- 
C) Contenido de los actos jurídicos internos. Se rigen por la normativa correspondiente a la regionalidad de la cooperativa, aun cuando se efectúen fuera de la región de residencia, según vimos ya al tratar de las sucursales establecidas en otro territorio (art. 9.11 del Código Civil).

D) Contenido de otros negocios jurídicos. Creemos de especial interés para las cooperativas las siguientes reglas:

a) La emisión de títulos laborales, en la medida en que las cooperativas pueden acordarlos se regirá por la ley del lugar en que tenga lugar la emisión (art. 10 del Código), ordinariamente la del domicilio principal de la entidad.

b) Las obligaciones contractuales entre entidades de distinta vecindad regional se regularán por la normativa a que las partes se sometan, a condición de que tengan conexión con el negocio jurídico, y de que la sumisión no implique fraude a la ley o abuso de derecho, más difícilmente ejercicio antisocial del mismo, visto el art. 10.5 del Código. Por supuesto en casos de regionalidad común a las partes contratantes, no habría conflicto de oposición entre dos ordenamientos territoriales, vista la vinculación entre residencia y regionalidad de las cooperativas. Esta regla también alcanza por igual al derecho cooperativo y al civil foral.

c) En caso de inexistencia del pacto de sumisión a un determinado ordenamiento se aplicará el correspondiente a la ubicación de los inmuebles objeto del contrato; tratándose de inmuebles el de radicación del establecimiento que realiza la operación, sea la sede principal de la cooperativa o una sucursal (visto el art. 10.5 del Código Civil). El Código se refiere expresamente a los contratos sobre inmuebles y a la compraventa de inmuebles; pero por analogía (en base al art. 4 del Código) la misma regla operará para otros contratos sobre inmuebles, por ejemplo su préstamo.

d) Las donaciones se regirán por la normativa del domicilio del donante, tanto si la cooperativa es donante como si es recipendiaria (art. 10.7).

E) Obligaciones extracontractuales. Se regularán por la normativa correspondiente al territorio en que tuvieron lugar los hechos que la

NES, «Hechos y actos jurídicos en la legislación iberoamericana», Anuario (argentino) de Derecho Civil, T. ${ }^{\circ}$ VI de 2001, págs. 43 y sig. 
ocasionen. No obstante, en el caso de la gestión de negocios ajenos, se aplicará la norma del lugar en que el gestor realice la actividad principal (art. 10.9 del Código).

F) Enriquecimiento sin causa. Se aplicará la legislación en virtud de la cual se produjo la trasferencia de valores a favor del enriquecido (art. 10.9 del Código Civil).

G) Derechos reales. Tanto si son muebles como inmuebles se aplicará como regla general el ordenamiento del lugar de ubicación, trátese de reglas de derecho civil o de derecho cooperativo (art. 10.1 del Código). No obstante, la constitución o cesión de derechos sobre bienes en tránsito se regirá por la norma del lugar de expedición, salvo que, de común acuerdo (expreso o tácito), remitente o destinatario decidan someterse a la normativa del lugar de destino (art. 10.1).

H) Ejecución oficial. Las modalidades de ejecución de las obligaciones que requieran intervención administrativa o judicial se regirán por la ley del lugar de cumplimiento de la obligación (art. 10.10 de Código civil). La competencia de la Inspección de Trabajo, en materia cooperativa inclusive, se rige asimismo por un principio de territorialidad (Ley 42/97 y R.D. 928/98). 